\title{
Prevention of Granulocyte-mediated Oxidant Lung Injury in Rats by a Hydroxyl Radical Scavenger, Dimethylthiourea
}

\author{
Richard B. Fox
}

Division of Cell Biology, Department of Medicine, Children's Hospital Medical Center and Department of Pediatrics, Harvard Medical School, Boston, Massachusetts 02115; Department of Pediatrics and the Webb-Waring Lung Institute, University of Colorado School of Medicine, Denver, Colorado 80262

bstract. Toxic, partially reduced metabolites of oxygen (toxic oxygen radicals) are increasingly implicated in acute leukocyte-mediated tissue injury. To further probe the roles of oxygen radicals in acute lung edema, I studied the effects of a recently described and very potent oxygen radical scavenger, dimethylthiourea (DMTU) (Fox, R. B., R. N. Harada, R. M. Tate, and J. E. Repine, 1983, J. Appl. Physiol., 55:1456-1459) on polymorphonuclear leukocyte (PMN) oxidant function and on two types of lung injury mediated by oxygen radicals and PMN. DMTU (10 mM) blocked $79 \%$ of hydroxyl radical $\left({ }^{\circ} \mathrm{OH}\right)$ production by $\mathrm{PMN}$ in vitro without interfering with other PMN functions, such as $\mathrm{O}_{2}^{-}$production, myeloperoxidase activity, chemotaxis, degranulation, or aggregation. When isolated rat lung preparations were perfused with PMN activated to produce $\mathrm{OH}$, lung weights were increased from $2.3 \pm 0.2$ to $11.2 \pm 0.8 \mathrm{~g}$. DMTU (10 $\mathrm{mM})$ prevented $70 \%$ of these increases (lung weights, 5.0 $\pm 1.1 \mathrm{~g}, P<0.005$ ). Finally, when intact rats were exposed to $100 \% \mathrm{O}_{2}$ for $66 \mathrm{~h}$, lung weight:body weight ratios were increased from $5.78 \pm 0.33$ to $8.87 \pm 0.16 \mathrm{~g}$. DMTU $(500 \mathrm{mg} / \mathrm{kg})$ prevented $83 \%$ of this hyperoxia-induced lung edema in vivo (lung:body weight ratios, $6.05 \pm 0.21, P<0.001)$. Pharmacokinetic

This work was presented in part at the meeting of the Western section of the American Federation for Clinical Research, Carmel, CA, February 1982 (Clin. Res. 30:71A) and the meeting of the American Thoracic Society, Los Angeles, CA, May 1982 (Am. Rev. Respir. Dis. 125[pt. 2]:149).

Address correspondence and reprint requests to Dr. Fox, Children's Hospital Medical Center, Boston, MA 02115. 1984

Received for publication 7 July 1982 and in revised form 28 June

J. Clin. Invest.

(c) The American Society for Clinical Investigation, Inc. 0021-9738/84/10/1456/09 \$1.00

Volume 74, October 1984, 1456-1464 studies showed that DMTU diffused effectively into lung interstitial fluids and had a relatively long half-life (25$35 \mathrm{~h}$ ) in the circulation. Because a variety of oxygen radicals, such as superoxide $\left(\mathrm{O}_{2}^{-}\right)$, hydrogen peroxide $\left(\mathrm{H}_{2} \mathrm{O}_{2}\right)$, or ${ }^{\circ} \mathrm{OH}$ are produced by $\mathrm{PMN}$, there is usually some uncertainty about which one is responsible for injury. However, in these studies, DMTU did not scavenge $\mathrm{O}_{2}^{-}$and scavenged $\mathrm{H}_{2} \mathrm{O}_{2}$ only very slowly while scavenging ${ }^{\circ} \mathrm{OH}$ very effectively. Therefore, DMTU may be useful in the investigation of the roles of oxygen radicals, especially ${ }^{\circ} \mathrm{OH}$, in acute granulocyte-mediated tissue injury.

\section{Introduction}

Highly reactive, partially reduced metabolites of oxygen (toxic oxygen radicals) have been implicated in the pathogenesis of acute tissue injury, particularly in the lung (1-3). One likely source of oxygen radicals in tissues is the polymorphonuclear leukocyte (PMN), which produces large amounts of oxygen radicals in its phagolysosomes as a bactericidal mechanism (4). Activated PMN can cause acute lung injury by leaking these potent oxidants into lung tissues (5-8).

The contribution of PMN-derived oxidants to acute tissue injury has been demonstrated using antioxidant enzymes or chemicals to block PMN-induced injury, either in isolated perfused organs (3) or in whole animals (7-8). However, antioxidant enzymes, such as superoxide dismutase (SOD) ${ }^{1}$ and/or catalase are large charged proteins and may not always penetrate nonperfused areas or provide protection inside cells (9). Furthermore, there are no known enzymatic scavengers of the most highly reactive oxygen radical, the hydroxyl radical $\left({ }^{\circ} \mathrm{OH}\right)$. While chemical scavengers of ${ }^{\circ} \mathrm{OH}$, such as ethanol and mannitol, are known and used, these agents may lack potency;

1. Abbreviations used in this paper: AM, alveolar macrophage; DMSO, dimethylsulfoxide; DMTU, dimethylthiourea; HPO, horseradish peroxidase; MPO, myeloperoxidase; PMA, phorbol myristate acetate; SOD, superoxide dismutase; ZAS, zymosan-activated serum. 
that is, they may not effectively scavenge ${ }^{\circ} \mathrm{OH}$ when used in concentrations which are not toxic in vivo (see Results).

To overcome these limitations, I used dimethylthiourea (DMTU) as an antioxidant to prevent oxidant lung injury in vitro and in vivo. DMTU is a recently described derivative of thiourea which does not cause the massive pulmonary edema characteristic of thiourea (10) and many other thiourea derivatives (11), but remains a highly effective ${ }^{\circ} \mathrm{OH}$ scavenger. Specifically, DMTU blocked ${ }^{\circ} \mathrm{OH}$ production by PMN but was not toxic to other PMN functions. It decreased PMN-mediated edema in the isolated-perfused rat lung and also protected intact rats against lung edema due to pulmonary oxygen toxicity, a process in which both oxygen radicals and PMN have been implicated (12-17). These findings suggest that DMTU may be a useful probe in the study of the contributions of oxidants in tissue injury.

\section{Methods}

Determination of ${ }^{\circ} \mathrm{OH}$ scavenging. ${ }^{\circ} \mathrm{OH}$ was quantitated by measuring its ability to decompose dimethylsulfoxide (DMSO) to methane, as previously described (18). ${ }^{\circ} \mathrm{OH}$ was generated by irradiating $\left({ }^{60} \mathrm{Co}, 700\right.$ rad) solutions $(1 \mathrm{ml})$ consisting of $100 \mathrm{mM}$ potassium phosphate $(\mathrm{pH}$ $=7.4$ ) and $10 \mathrm{mM}$ DMSO (Sigma Chemical Co., St. Louis, MO) in 4 $\mathrm{ml}$ rubber-stoppered glass tubes (Vacutainer, Becton-Dickinson Co., Rutherford, NJ), which were washed prior to use. DMTU (Alpha Products, Danvers, MA), thiourea (J. T. Baker Chemical Co., Phillipsburg, NJ), ethanol (U. S. Pharmacopeia), or mannitol (Sigma Chemical Co.) were added to some solutions. After stoppering, tubes were gassed with nitrous oxide $\left(\mathrm{N}_{2} \mathrm{O}\right.$, U. S. Pharmacopeia) by means of injection needles placed through the stoppers and then tumbled for $15 \mathrm{~min}$ to equilibrate solutions with $\mathrm{N}_{2} \mathrm{O}$. Inclusion of $\mathrm{N}_{2} \mathrm{O}$ in irradiated solutions increases yield of ${ }^{\circ} \mathrm{OH}$ and decreases yield of other radicals, such as $\mathrm{e}_{\mathrm{aq}}^{-}$(hydrated electron) and $\mathrm{O}_{2}^{-}$, establishing a nearly one radical ( $(\mathrm{OH})$ system (19). After irradiation, methane concentrations of the headspace gases were determined by standard gas chromatography (model GC55 gas chromatograph, Beckman Instruments, Fullerton, CA), using authentic methane (Supelco, Inc., Bellafonte, PA) as standard, as previously described (18).

Determination of effect of DMTU on $\mathrm{O}_{2}^{-}$and ${ }^{\circ} \mathrm{OH}$ production by $P M N$. Human PMN were isolated by Ficoll-Hypaque sedimentation and resuspended in Hanks' balanced salt solution containing $\mathrm{Ca}^{++}$and $\mathrm{Mg}^{++}$(HBSS, Gibco Laboratories, Grand Island, NY), as previously described (18). PMN production of $\mathrm{O}_{2}^{-}$was measured by spectrophotometric determination of SOD $(0.1 \mathrm{mg} / \mathrm{ml}$, Sigma Chemical Co. inhibitable reduction of cytochrome $c(0.12 \mathrm{mM}$, Sigma Chemical Co. by PMN stimulated with phorbol myristate acetate (PMA, $1 \mu \mathrm{g} / \mathrm{ml}$, Consolidated Midland Corp., Brewster, NY), as previously described (18). PMN production of $\mathrm{OH}$ was measured by PMN decomposition of DMSO to methane, as previously described (17). Solutions $(1 \mathrm{ml})$ of DMSO (10 mM) in HBSS, which contained human PMN (1.6 $\left.\times 10^{7}\right)$ stimulated by PMA $(1 \mu \mathrm{g} / \mathrm{ml})$, in rubber-stoppered glass tubes (as above) were incubated in air at $37^{\circ} \mathrm{C}$ with slow tumbling for 30 min. Reactions were then terminated by immersion in ice water and headspace methane concentrations determined as above.

Determination of effect of DMTU on peroxidase activity. Peroxidase activity was assayed by measuring its capacity to catalyze the oxidation of pyrogallol by $\mathrm{H}_{2} \mathrm{O}_{2}(20-21)$. Peroxidase activity was determined from the change in absorbance at $420 \mathrm{~nm}$ of a solution of $0.5 \%$ pyrogallol, $1 \mathrm{mM} \mathrm{H}_{2} \mathrm{O}_{2}$, and $0.05 \mathrm{U} / \mathrm{ml}$ horseradish peroxidase (HPO) (all from Sigma Chemical Co.) in $20 \mathrm{mM}$ potassium phosphate (pH $=6.0$ ). . To determine whether DMTU affected this reaction by inhibiting HPO or by scavenging $\mathrm{H}_{2} \mathrm{O}_{2}$, DMTU was added to some solutions after HPO but before $\mathrm{H}_{2} \mathrm{O}_{2}$, while in other assays DMTU was added to the solution after $\mathrm{H}_{2} \mathrm{O}_{2}$ but 5 min before HPO. In additional studies, the effect of DMTU on myeloperoxidase (MPO) activity was also determined by the same method. Human PMN $\left(7.8 \times 10^{6} / \mathrm{ml}\right)$ were lysed with $15 \mu \mathrm{l} / \mathrm{ml}$ of Nonidet P-40 (Sigma Chemical Co.), centrifuged at $500 \mathrm{~g}$, and the supernatants recovered. Peroxidase activities of the supernatants, in the presence and absence of DMTU (5 or $10 \mathrm{mM})$, were determined from the change in absorption $(420 \mathrm{~nm})$ of solutions of supernatant $(50 \mu \mathrm{l} / \mathrm{ml}), 0.5 \%$ pyrogallol, and $1 \mathrm{mM} \mathrm{H}_{2} \mathrm{O}_{2}$ in 20 $\mathrm{mM}$ potassium phosphate $(\mathrm{pH} 6.0)$.

Determination of effect of DMTU on PMN chemotaxis. Chemotaxis of human PMN in various concentrations of DMTU was determined by the agarose method (22). DMTU $(2,5$, and $10 \mathrm{mM}$ final concentrations) was incorporated into agarose $(0.75 \%)$-gelatin $(0.25 \%)$ just prior to gelling so as not to oxidize the DMTU by heating. Three wells $(2 \mathrm{~mm})$ were cut in the agarose with an interwell distance of $2 \mathrm{~mm}$. PMN were placed in the central well, zymosan-activated serum (ZAS) (18) in one peripheral well, and saline (control) in the other peripheral well. Plates were incubated at $37^{\circ} \mathrm{C}$ for $2 \mathrm{~h}$, fixed with methanol (90\%)formalin (10\%), and Wright's stained. The leading fronts of chemotaxis (ZAS) and chemokinesis (saline) were determined by microscopy and the chemotactic index ([chemotaxis-chemokinesis]/chemokinesis) calculated.

Determination of effect of DMTU on PMN degranulation. Degranulation of human PMN $\left(1 \times 10^{7} / \mathrm{ml}\right.$ in HBSS $)$ was induced by opsonized zymosan particles (10:1 zymosan:PMN) in the presence or absence of $10 \mathrm{mM}$ DMTU. Cell suspensions were incubated at $37^{\circ} \mathrm{C}$ for $2 \mathrm{~min}$ after addition of opsonized zymosan and then centrifuged $(500 \mathrm{~g})$. Granule enzymes were released from some cell suspensions by treatment with a detergent (Nonidet P-40). Activities in supernatants of Bglucuronidase (phenolphthalein glucuronic acid substrate, Sigma Chemical Co., 23, 24) and lactate dehydrogenase (25) were determined by standard methods. Vitamin $B_{12}$ binding protein contents of supernatants were determined by a radioligand binding assay (26). ${ }^{57} \mathrm{Co}-$ labeled cyanocobalamin $(5.25 \mathrm{ng})$ was incubated with supernatant $(300$ $\mu 1)$ and saline $(450 \mu \mathrm{l})$ at room temperature for $5 \mathrm{~min}$ after which albuminin-coated charcoal $(500 \mu \mathrm{l})$ was added. After centrifugation $(1000 \mathrm{~g})$, the supernatants were counted in a gamma scintillation counter (Searle Diagnostics, Inc., Skokie, IL).

Determination of effect of DMTU on PMN aggregation. Aggregation of human PMN was determined by aggregometry of PMN $\left(4 \times 10^{6}\right)$ in $1 \mathrm{ml}$ of HBSS plus $0.5 \%$ human serum albumin in an aggregometer (model PAP-2A, Bio/Data Corp., Willow Grove, PA) after stimulation with zymosan-activated human serum $(50 \mu l, 27)$.

$P M N$ perfusion of isolated rat lungs. Human peripheral blood PMN were isolated as described above. Heart-lung preparations were isolated from 350-400 g Sprague-Dawley rats (Charles River Breeding, Inc., Wilmington, MA). After satisfactory anesthesia was obtained with pentobarbital, rats were anticoagulated with heparin. A tracheostomy was placed and rats were continuously ventilated $(10 \mathrm{ml} / \mathrm{kg})$ for the duration of the experiment with a rodent ventilator (Harvard Apparatus Co., South Natick, MA). After opening the chest by sternectomy and exsanguinating by transecting the inferior vena cava, a polyethylene catheter was placed through a right ventriculotomy into the main pulmonary artery and tied. A large bore polyethylene catheter was 
then placed into the left ventricle through an apical left ventriculotomy and tied in place. Perfusion of the lungs then commenced at a rate of $9 \mathrm{ml} / \mathrm{min}$ with HBSS (Gibco Laboratories, Grand Island, NY) containing 4\% bovine serum albumin (Sigma Chemical Co.). Dissection of the heart-lung unit was then completed and the preparation suspended in a warmed humidified environment. In some preparations, PMA $(0.25$ $\mu \mathrm{g} / \mathrm{ml})$ was added to the perfusate reservoir and/or PMN $\left(3 \times 10^{7}\right)$ were injected slowly (over 2-4 min) into the pulmonary artery catheter. Pulmonary artery pressures were measured using Statham transducers and a multichannel recorder (both from Gilson Medical Electronics, Middleton, WI). After $45 \mathrm{~min}$ of perfusion, the lungs (minus heart) were weighed and then lavaged once with $10 \mathrm{ml}$ of saline. Albumin concentrations of the lavages were determined spectrophotometrically by a brom-cresol green dye binding method $(28,29)$.

Determination of DMTU pharmacokinetics in rats and sheep. With pentobarbital anesthesia, heparinized polyethylene catheters were placed in the right common carotid arteries of rats $(400 \mathrm{~g})$ by cutdown, and tunneled subcutaneously to the backs of the necks and exteriorized there. After allowing $24 \mathrm{~h}$ for recovery from surgery, rats were injected intraperitoneally with DMTU at a dose of $500 \mathrm{mg} / \mathrm{kg}(200 \mathrm{mg}$ in 4 $\mathrm{ml}$ of normal saline). Heparinized blood samples $(1 \mathrm{ml})$ were drawn before dosing with DMTU and at 1,4 , and $8 \mathrm{~h}$ after dosing. Circulating blood volume was maintained by intra-arterial volume expansion (1.5 $\mathrm{ml}$ ) with normal saline plus $4 \%$ bovine serum albumin (at 0 and $1 \mathrm{~h}$ ) or heparinized whole rat blood (at $4 \mathrm{~h}$ ). Additional pharmacokinetic studies were performed in sheep fitted with chronic lung lymph fistulas to determine the concentrations of DMTU in lung lymph as compared with plasma. 1-2-yr-old sheep were fitted with carotid and pulmonary artery catheters, and with lung lymph fistulas as previously described (30); care was taken to prevent any diaphragmatic contributions to lung lymph flow. DMTU in a dose of $1.0 \mathrm{~g} / \mathrm{kg}$ was given by intravenous infusion in lactated Ringer's solution over $30 \mathrm{~min}$. Lymph and blood samples were collected at $0,1,4,6$, and $24 \mathrm{~h}$.

Plasma and lymph levels of DMTU were determined by high pressure liquid chromatography (HPLC) (31). Plasma was separated from blood by centrifugation $(200 \mathrm{~g})$. Samples were mixed vigorously with $2.5 \mathrm{vol}$ of absolute ethanol and then centrifuged $(500 \mathrm{~g}$ for 10 min). The resulting supernatants were dried under nitrogen. The product was dissolved in $1 \mathrm{ml}$ of methanol and chromatographed on a C18 Radial-Pak HPLC column (Waters Associates, Millipore Corp., Milford, MA) with a mobile phase of $5 \%$ methanol:95\% water at a flow rate of $3 \mathrm{ml} / \mathrm{min}$ and detection at $254 \mathrm{~nm}$ (model 441 absorbance detector, Waters Associates). Authentic DMTU (Alpha Products) was used to standardize the assay. Pharmacokinetic parameters of DMTU metabolism were determined from a standard one compartment open model (32).

Measurement of ${ }^{\circ} \mathrm{OH}$ scavenging by serum from DMTU-treated rats. Sprague-Dawley rats $(300 \mathrm{~g}$, Charles River Breeding Laboratories, Inc.) were injected with DMTU ( $500 \mathrm{mg} / \mathrm{kg}$ intraperitoneally) or equal volumes of saline. $2 \mathrm{~h}$ later, rats were sacrificed in a carbon dioxide chamber. Blood was obtained by open chest cardiac puncture and sera isolated by centrifugation $(500 \mathrm{~g} \times 10 \mathrm{~min})$. Solutions $(1 \mathrm{ml})$ consisting of $80 \%$ serum, $100 \mathrm{mM}$ potassium phosphate $(\mathrm{pH}=7.4)$, and $10 \mathrm{mM}$ DMSO were placed in rubber-stoppered glass tubes (as above), gassed with $\mathrm{N}_{2} \mathrm{O}$, irradiated $(700 \mathrm{rad})$, and headspace methane concentrations determined as above.

Measurement of effect of DMTU on hyperoxia-induced lung edema. Rats were exposed to $100 \% \mathrm{O}_{2}(40 \mathrm{liter} / \mathrm{min})$ at a barometric pressure of 730 torr. Some rats were treated with DMTU injected at the beginning of $\mathrm{O}_{2}$ exposure $(500 \mathrm{mg} / \mathrm{kg}$ intraperitoneally) and every 12 $\mathrm{h}$ thereafter $(125 \mathrm{mg} / \mathrm{kg}$ intraperitoneally). Controls were injected with equal volumes of saline on a similar schedule. After $66 \mathrm{~h}$ of $100 \% \mathrm{O}_{2}$ exposure, rats were removed from the hyperoxia chamber. All rats survived at least $30 \mathrm{~min}$ after termination of $\mathrm{O}_{2}$ exposure. Rats were then sacrificed with pentobarbital, weighed, and exsanguinated by open-chest cardiac puncture. Their lungs were removed, weighed, and lavaged five times with $10 \mathrm{ml}$ of saline. Pleural effusion volumes were determined at the time of chest opening by aspiration into graduated syringes. Albumin concentrations of the first aliquot of lung lavage were determined as above. Leukocytes in lavages and cardiac blood were counted in a hemocytometer and differential counts were performed on Wright's stained cytocentrifuge preparations (lavages) or smears (blood).

Statistical methods. Significances of differences between and among groups were determined by Student's $t$ test or analysis of variance, as appropriate, using two-tailed distributions and standard methods (33).

\section{Results}

-OH radical scavenging effectiveness of DMTU. To determine the ${ }^{\circ} \mathrm{OH}$ scavenging effectiveness of DMTU in vitro, the ability of DMTU to inhibit ${ }^{\circ} \mathrm{OH}$-mediated methane production from solutions of DMSO was measured. Solutions were exposed to 'OH generated by gamma irradiation of water in the presence of nitrous oxide. Inhibition of methane production from irradiated DMSO by DMTU $(85 \pm 2 \%)$ was similar or better than thiourea $(69 \pm 5 \%)$, and was more effective than two other

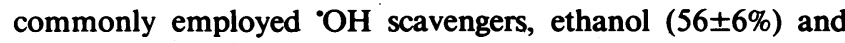
mannitol (no inhibition), when the concentration of each scavenger was $10 \mathrm{mM}$ (Table I).

Effect of DMTU on $\mathrm{O}_{2}^{-}$and ${ }^{\circ} \mathrm{OH}$ production by $P M N$. Because production of toxic oxygen radicals from PMN can cause acute lung injury (5-8), the effectiveness of DMTU in scavenging oxygen radicals, such as $\mathrm{O}_{2}^{-}$and ${ }^{\circ} \mathrm{OH}$, produced by

Table I. Effect of $\cdot$ OH Scavengers on Methane Production from Irradiated DMSO*

\begin{tabular}{lcc}
\hline & $\begin{array}{l}\text { Methane produced } \\
(p p b)\end{array}$ & Inhibition \\
\hline Additions & & $\%$ \\
& & $\%$ \\
DMSO & $2818 \pm 124(8) \ddagger$ & 0 \\
DMSO + DMTU (2 mM) & $2709 \pm 227(4) \S$ & $4 \pm 8$ \\
DMSO + DMTU (5 mM) & $1776 \pm 189(4)^{\prime \prime}$ & $37 \pm 7$ \\
DMSO + DMTU (10 mM) & $427 \pm 58(4)^{\prime \prime}$ & $85 \pm 2$ \\
DMSO + thiourea (10 mM) & $822 \pm 144(4)^{\prime \prime}$ & $69 \pm 5$ \\
DMSO + ethanol (10 mM) & $946 \pm 330(3)^{\prime \prime}$ & $56 \pm 6$ \\
DMSO + mannitol $(10 \mathrm{mM})$ & $4030 \pm 354(4) \S$ & \\
\end{tabular}

* ppb, parts per billion. DMSO (10 mM in sodium phosphate, 100 $\mathrm{mM}, \mathrm{pH}=7.4)$ was exposed to gamma irradiation $\left({ }^{60} \mathrm{Co}, 700 \mathrm{rad}\right)$ in the presence of nitrous oxide.

$\ddagger$ Mean \pm SEM $(n)$.

$\S$ Not significantly less $(P>0.05)$ than samples with no scavenger.

"Significantly less $(P<0.05)$ than samples with no scavenger. 
PMN activated by PMA was determined. While DMTU (up to $10 \mathrm{mM}$ ) did not diminish $\mathrm{PMN}$ production of $\mathrm{O}_{2}^{-}$, as measured by cytochrome $c$ reduction, modest concentrations of DMTU ( $2 \mathrm{mM}$ ) significantly inhibited net ${ }^{\circ} \mathrm{OH}$ production by PMN, as determined by methane production from DMSO (Table II). This decreased net ${ }^{\circ} \mathrm{OH}$ production by PMN did not result from a generalized toxic effect of DMTU on PMN oxidative metabolism, as evidenced by no decrease in $\mathrm{O}_{2}^{-}$ production by $\mathrm{PMN}$ in the presence of concentrations of DMTU of up to $10 \mathrm{mM}$. Indeed, $\mathrm{O}_{2}^{-}$production by $\mathrm{PMN}$ was significantly increased by DMTU.

$\mathrm{H}_{2} \mathrm{O}_{2}$ scavenging by DMTU. Because DMTU inhibited - $\mathrm{OH}$ production but not $\mathrm{O}_{2}^{-}$production by $\mathrm{PMN}$ and because ${ }^{\circ} \mathrm{OH}$ is derived from $\mathrm{O}_{2}^{-}$, it appeared that DMTU exerted its antioxidant effect on PMN function subsequent to the formation of $\mathrm{O}_{2}^{-}$. Specifically, $\mathrm{O}_{2}^{-}$can be metabolized to $\mathrm{H}_{2} \mathrm{O}_{2}$ which can then subsequently interact with additional $\mathrm{O}_{2}^{-}$via the Haber-Weiss mechanism to form ${ }^{\circ} \mathrm{OH}$ (see Discussion). Therefore, while the studies above showed clearly the $\mathrm{OH}$ scavenging activity of DMTU when ${ }^{\circ} \mathrm{OH}$ was generated directly (without $\mathrm{O}_{2}^{-}$or $\mathrm{H}_{2} \mathrm{O}_{2}$ precursors) from radiation, it is important to consider the possibility that, in the $\mathrm{PMN}$, $\mathrm{OH}$ production could also be decreased by scavenging of $\mathrm{H}_{2} \mathrm{O}_{2}$ by DMTU. Earlier reports of reaction of thiourea with $\mathrm{H}_{2} \mathrm{O}_{2}$ supported this possibility (34).

Because the absorption spectrum of DMTU interferes with the standard spectrophotometric assays for $\mathrm{H}_{2} \mathrm{O}_{2}$ (35), the ability of DMTU to inhibit a $\mathrm{H}_{2} \mathrm{O}_{2}$-dependent reaction, oxidation of pyrogallol by $\mathrm{HPO}$ and $\mathrm{H}_{2} \mathrm{O}_{2}$, was determined.

Table II. Effect of DMTU on Net Production of $\mathrm{O}_{2}^{-}$and $\cdot \mathrm{OH}$ by PMN In Vitro*

\begin{tabular}{lll}
\hline Test conditions & $\begin{array}{l}\text { Cytochrome } c \\
\text { reduced } f\end{array}$ & $\begin{array}{l}\text { Methane produced } \\
(p p b) \S\end{array}$ \\
\hline & $n m o l$ \\
PMN & $1.6 \pm 0.2(4)^{\prime \prime}$ & \\
PMN + PMA & $74.7 \pm 5.3(4)$ & $2208 \pm 161(5)$ \\
PMN + PMA + DMTU & & \\
$\quad(2 \mathrm{mM})$ & $103.0 \pm 3.1(4)$ & $440 \pm 277(5)^{* *}$ \\
$\begin{array}{l}\text { PMN + PMA + DMTU } \\
(5 \mathrm{mM})\end{array}$ & $99.9 \pm 1.3(4)$ & $387 \pm 287(5)^{* *}$ \\
$\begin{array}{l}\text { PMN + PMA + DMTU } \\
(10 \mathrm{mM})\end{array}$ & $98.9 \pm 1.8(4)$ & $466 \pm 242(5)^{* *}$
\end{tabular}

* "Net Production" refers to the amount of radical detectable in the presence of scavenger.

$\ddagger$ Nanomoles SOD inhibitable cytochrome $c$ reduced per $2 \times 10^{6}$ $\mathrm{PMN} / 30 \mathrm{~min}$.

$\S$ Parts per billion (ppb) of methane in headspace gas produced from DMSO per $1.6 \times 10^{7} \mathrm{PMN} / 30 \mathrm{~min}$

"Mean $\pm \operatorname{SEM}(n)$.

I PMA $(1 \mu \mathrm{g} / \mathrm{ml})$.

** Significantly less $(P<0.001)$ than samples without DMTU.
Under the test conditions employed, $10 \mathrm{mM}$ DMTU did not significantly inhibit this reaction (Table III). To determine whether DMTU scavenged $\mathrm{H}_{2} \mathrm{O}_{2}$, DMTU was added to the $\mathrm{H}_{2} \mathrm{O}_{2}$-containing substrate $5 \mathrm{~min}$ before the $\mathrm{HPO}$ was added to allow time for prior reaction of DMTU with $\mathrm{H}_{2} \mathrm{O}_{2}$. Under these circumstances, $10 \mathrm{mM}$ DMTU showed a slight but nonsignificant tendency to inhibit the reaction. Moreover, since the reaction velocity $5 \mathrm{~min}$ after combining DMTU with $\mathrm{H}_{2} \mathrm{O}_{2}$ was at least $90 \%$ of that seen immediately after combining them, the second order rate constant could be estimated to be on the order of $10^{-1} \mathrm{M}^{-1} \mathrm{~s}^{-1}$ or less, which is considerably less than that for thiourea, $1.2 \times 10^{10} \mathrm{M}^{-1} \mathrm{~s}^{-1}$ (19), which is about that of DMTU as shown in Table $I$.

Because MPO contributes to the bactericidal activities of PMN (36) and thus could contribute to PMN-mediated lung injury, additional studies of the effects of DMTU on MPO activity were performed. DMTU (up to $10 \mathrm{mM}$ ) did not significantly inhibit MPO activity (Table III).

Effect of DMTU on PMN chemotaxis. Since locomotion is an important PMN function which may contribute to PMNmediated lung injury, the effects of DMTU on PMN chemotaxis (directed migration) and chemokinesis (random migration) were determined. While there was no significant effect of DMTU on chemokinesis, there was a significant $(P<0.01)$ increase in chemotaxis in response to ZAS in the presence of DMTU in concentrations of 2,5 , and $10 \mathrm{mM}$ (Table IV).

Effect of DMTU on PMN degranulation. Since PMN contain a variety of proteolytic enzymes stored within two types of intracellular granules (specific and azurophilic granules) which could contribute to tissue injury, the effect of DMTU on PMN degranulation was determined. DMTU (10 mM) did not significantly diminish degranulation of either a specific granule-associated enzyme, vitamin $\mathbf{B}_{12}$ binding protein (37), or an azurophilic enzyme, B-glucuronidase (Table V). Control studies also showed that DMTU did not interfere with the assays for these enzymes as evidenced by a lack of effect of DMTU on the activities of enzymes released from PMN by detergent (Nonidet P-40). In additional control studies, lactate

Table III. Effect of DMTU on Peroxidase Activities of HPO and MPO

\begin{tabular}{ll}
\hline Test conditions & Change in absorbance $420 / \min$ \\
\hline HPO & $0.709 \pm 0.004(5)^{*}$ \\
HPO + DMTU (10 mM) & $0.715 \pm 0.008(4)$ \\
HPO + DMTU (10 mM) & $0.689 \pm 0.026(4)$ \\
MPO & $0.106 \pm 0.005(4)$ \\
MPO + DMTU (5 mM) & $0.098 \pm 0.002(5)$ \\
MPO + DMTU (10 mM) & $0.095 \pm 0.002(3)$
\end{tabular}

* Mean $\pm \operatorname{SEM}(n)$.

‡ DMTU combined with $\mathrm{H}_{2} \mathrm{O}_{2} 5 \mathrm{~min}$ before addition of $\mathrm{HPO}$. $\S$ From PMN lysates $\left(4 \times 10^{5} / \mathrm{ml}\right)$. 
Table IV. Effect of DMTU on PMN Chemotaxis

\begin{tabular}{|c|c|c|c|}
\hline Test conditions & $\begin{array}{l}\text { Chemotactic } \\
\text { index* }\end{array}$ & $\begin{array}{l}\text { Absolute } \\
\text { chemotaxis }\end{array}$ & Chemokinesis \\
\hline $\begin{array}{l}\text { PMN + ZAS } \\
\text { PMPN + ZAS }\end{array}$ & $3.50 \pm 0.05(18) \S$ & $2.79 \pm 0.03(18)$ & $1.13 \pm 0.016(18)$ \\
\hline + DMTU (2 mM) & $3.98 \pm 0.04(30)^{\prime \prime}$ & $3.49 \pm 0.05(30)^{\prime \prime}$ & $1.17 \pm 0.012(30)$ \\
\hline $\begin{array}{l}\text { PMN + ZAS } \\
\quad+\text { DMTU (5 mM) }\end{array}$ & $3.82 \pm 0.05(26)^{\prime \prime}$ & $2.95 \pm 0.03(26)^{\prime \prime}$ & $1.05 \pm 0.015$ \\
\hline $\begin{array}{l}\text { PMN + ZAS } \\
\quad+\text { DMTU }(10 \mathrm{mM})\end{array}$ & $4.00 \pm 0.06(27)^{\prime \prime}$ & $3.37 \pm 0.07(27)^{\prime \prime}$ & $1.12 \pm 0.012(27)$ \\
\hline
\end{tabular}

* Chemotactic index $=$ (chemotaxis - chemokinesis $) /$ chemokinesis; absolute chemotaxis $=$ chemotaxis - chemokinesis .

$\ddagger$ ZAS (100\%)

$\S$ Mean \pm SEM $(n)$

"Significantly greater $(P<0.05)$ than chemotaxis without DMTU.

dehydrogenase release into supernatants was similar with either unstimulated or stimulated cells and either in the presence or absence of DMTU, indicating that cell lysis did not contribute to the differences between the groups.

Effect of DMTU on PMN aggregation. Because PMN aggregation within the pulmonary vasculature has been proposed to contribute to lung injury (38), the effects of DMTU on PMN aggregation in response to ZAS were determined. DMTU (10 mM) did not significantly inhibit PMN aggregation (Fig. 1).

Protection of isolated-perfused rat lungs from PMN-mediated edema by DMTU. Since the preceding studies indicated that DMTU scavenges $\mathrm{OH}$ produced by $\mathrm{PMN}$ without impairing other important PMN functions (including $\mathrm{O}_{2}^{-}$production), it appeared that DMTU might be effective in preventing granulocyte-mediated lung edema if this injury results from ${ }^{\circ} \mathrm{OH}$. Because PMN activated by PMA to produce toxic oxygen radicals can cause edema in isolated-ventilated rabbit lungs (6), this system was employed to investigate the ability of DMTU to block lung edema from granulocyte oxidants. As shown, perfusion of isolated ventilated rat lungs with PMAactivated PMN caused significant lung edema (Table VI). Neither PMN nor PMA alone caused significant edema. DMTU $(10 \mathrm{mM})$ added to the perfusates reduced this edema by nearly $70 \%$. Peak pulmonary artery pressures were similar in lungs perfused with PMA (66 \pm 9 mmHg), PMA plus PMN $(75 \pm 10$ $\mathrm{mmHg}$, and PMA plus PMN plus DMTU $(71 \pm 2 \mathrm{mmHg}$ ),

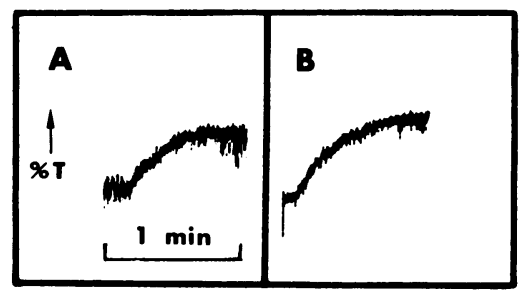

Figure 1. Similarity of PMN aggregation responses to ZAS in either the absence $(A)$ or presence $(B)$ of DMTU (10 mM). Aggregation responses were quantitated from the increases in light transmittance

$(\% \mathrm{~T})$ of PMN-containing solutions as measured by an aggregometer.
Table $V$. Effect of DMTU on Release of Specific and Azurophilic Granule-associated Proteins from Human PMN

\begin{tabular}{|c|c|c|c|}
\hline Test conditions & B-Glucuronidase* & $\begin{array}{l}\text { Vitamin B12 } \\
\text { binding¥ }\end{array}$ & LDH§ \\
\hline HBSS & $\mathbf{O}(2)^{\prime \prime}$ & $0(2)$ & $0(2)$ \\
\hline HBSS + PMN & $0.31 \pm 0.06(4)$ & $136 \pm 14(4)$ & $7.47 \pm 1.93(4)$ \\
\hline HBSS + PMN + OPZ & $0.57 \pm 0.05(6)$ & $381 \pm 23(6)$ & $6.47 \pm 1.12(6)$ \\
\hline HBSS + PMN + OPZ & & & \\
\hline + DMTU (10 mM) & $0.65 \pm 0.08(6)$ & $350 \pm 18(6)$ & $1.93 \pm 0.40(6)$ \\
\hline HBSS + PMN + DMTU & $0.32 \pm 0.01(2)$ & $153 \pm 5 \quad(2)$ & $3.34 \pm 0.11(2)$ \\
\hline HBSS + OPZ & $0(2)$ & $0(2)$ & $0(2)$ \\
\hline HBSS + DMTU & $0(2)$ & $0(2)$ & $0(2)$ \\
\hline $\begin{array}{l}\text { HBSS + PMN lysated } \\
\text { HBSS + PMN lysate }\end{array}$ & $26.0 \pm 0.04(3)$ & $25,608 \pm 1901(4)$ & $251 \pm 15(2)$ \\
\hline + DMT & $26.2 \pm 0.02(3)$ & $25,769 \pm 1786(4)$ & $270 \pm 3$ \\
\hline
\end{tabular}

LDH, lactic dehydrogenase; OPZ, opsonized zymosan.

* Micrograms of phenophthalein produced/50 $\mu$ l sample.

$\ddagger$ Counts per minute of ${ }^{57} \mathrm{Co}$-labeled vitamin $B_{12}$ bound/300 $\mu \mathrm{l}$ of supernatant.

$\S$ Change in absorbance at $340 \mathrm{~nm} / \mathrm{min} \times 10^{3}$.

"Mean \pm SEM $(n)$.

I $10^{5}$ PMN per milliliter lysed with $1 \%$ Nonidet P-40.

while PMN alone did not increase pressures $(20 \pm 2 \mathrm{mmHg})$ above base line.

Pharmacokinetics of DMTU in rats. While the ${ }^{\circ} \mathrm{OH}$ scavenging potential of DMTU appeared promising in these in vitro studies, equivalent success in vivo would necessitate the achievement of similar concentrations in serum of animals treated with DMTU. Therefore, the pharmacokinetics of DMTU were investigated by injecting rats intraperitoneally with DMTU $(500 \mathrm{mg} / \mathrm{kg})$ and collecting samples of blood from indwelling carotid artery catheters at 1,4 , and $8 \mathrm{~h}$. The average plasma concentration of DMTU was $3.64 \mathrm{mM}(382$ $\mu \mathrm{g} / \mathrm{ml}$ ) at $1 \mathrm{~h}$ and fell very slowly thereafter with an apparent half-life of $\sim 34 \mathrm{~h}$ (Table VII). To determine the ability of DMTU to penetrate the interstitial fluid compartment, the concentrations of DMTU in serum and lung lymph from sheep treated with DMTU $(1000 \mathrm{mg} / \mathrm{kg}$ intravenously) were also determined. Although DMTU concentrations in lung lymph $(5.47 \pm 1.25 \mathrm{mM})$ were slightly less than serum concentrations $(7.74 \pm 0.62)$ at $1 \mathrm{~h}$ after treatment, serum concentrations then dropped below lymph concentrations by $4 \mathrm{~h}$. The serum half-life in sheep was about $25 \mathrm{~h}$.

Hhydroxyl radical production in sera of DMTU-treated rats. To determine whether DMTU retained its ${ }^{\circ} \mathrm{OH}$ scavenging activity in vivo, rats were injected intraperitoneally with DMTU $(500 \mathrm{mg} / \mathrm{kg})$ and exsanguinated $2 \mathrm{~h}$ later. The sera were then assayed for ${ }^{\circ} \mathrm{OH}$-scavenging potential by measuring methane production from irradiated DMSO in the presence of these sera as described earlier. Methane production, which was $2530 \pm 168$ parts per billion in the presence of serum from saline-treated rats, was decreased to $1904 \pm 158$ parts per billion in the presence of serum from DMTU-treated rats $(P<0.05)$.

Effect of DMTU on hyperoxia-induced lung edema. Because the oxidant effects of PMN in vitro could be blocked by 
Table VI. Effect of DMTU on PMN-mediated Edema in Isolated Rat Lungs

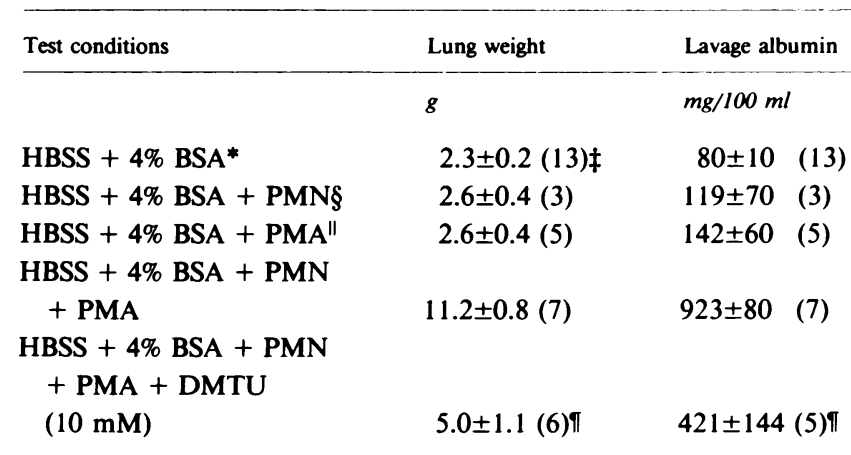

* HBSS $+4 \%$ bovine serum albumin (BSA).

$\ddagger$ Mean \pm SEM $(n)$.

$\S 3 \times 10^{7} \mathrm{PMN} /$ lung.

" PMA (1 $\mu \mathrm{g} / \mathrm{ml})$.

I Significantly less $(P<0.005)$ than PMN-PMA treated lungs.

concentrations of DMTU achievable in vivo, it appeared possible that DMTU might protect against oxidant lung injury in vivo. The injury chosen for these studies was pulmonary oxygen toxicity since evidence suggests that this injury results from oxygen radicals produced by lung cells exposed to hyperoxia (12-14), perhaps augmented by oxidants produced by influxes of PMN (15-17). Treatment of rats with a loading dose of DMTU $(500 \mathrm{mg} / \mathrm{kg}$ intraperitoneally) followed by repeat treatments every $12 \mathrm{~h}(125 \mathrm{mg} / \mathrm{kg}$ intraperitoneally) very significantly reduced lung edema when measured after 66 h of exposure to $100 \% \mathrm{O}_{2}$ (Table VIII). DMTU treatment prevented $83 \%$ of increases in lung weight:body weight ratios, $100 \%$ of pleural effusions, and $73 \%$ of increases in lung lavage albumin concentrations $(P<0.01$ in each case).

Table VII. Pharmacokinetics of DMTU in Rats and Sheep

\begin{tabular}{|c|c|c|c|}
\hline \multirow[b]{2}{*}{ Species } & \multirow{2}{*}{$\begin{array}{l}\text { Time } \\
\text { after } \\
\text { dose }\end{array}$} & \multicolumn{2}{|c|}{ DMTU concentration $(m M)$} \\
\hline & & Plasma & Lymph \\
\hline & $h$ & & \\
\hline \multirow[t]{4}{*}{ Rats } & 1 & $3.64 \pm 0.39(4)^{*}$ & ND \\
\hline & 4 & $3.49 \pm 0.48(3)$ & ND \\
\hline & 8 & $3.16 \pm 0.43(3)$ & ND \\
\hline & & Half-life: $34 \mathrm{~h}$ & \\
\hline \multirow[t]{5}{*}{ Sheep } & 1 & $7.74 \pm 0.62(5)$ & $5.47 \pm 1.25(4)$ \\
\hline & 4 & $6.30 \pm 0.40(4)$ & $6.58 \pm 0.76(3)$ \\
\hline & 6 & $6.07 \pm 0.60$ & $6.66 \pm 0.47(3)$ \\
\hline & 24 & $3.87 \quad(1)$ & $4.51 \quad(1)$ \\
\hline & & Half-life: $25 \mathrm{~h}$ & \\
\hline
\end{tabular}

ND, not determined.

* Mean $\pm \operatorname{SEM}(n)$.
Since phagocytes such as PMN and alveolar macrophages (AM) may be involved in lung injury due to hyperoxia (1517,39 ), the numbers of PMN and AM in lung lavages as well as numbers of PMN in blood were determined. Exposure of rats to hyperoxia for $66 \mathrm{~h}$ caused increased numbers of both PMN and AM in lung lavages and increased numbers of PMN in blood (Table VIII). DMTU treatment blunted the increases in $\mathrm{AM}$ in lavage and $\mathrm{PMN}$ in blood but did not significantly $(P>0.05)$ decrease the influx of PMN seen in lavages. In control studies, DMTU treatment of rats exposed to normoxia did not significantly affect numbers of PMN or AM in lavages or PMN in blood.

\section{Discussion}

In the present investigations, DMTU effectively prevented lung edema in vitro and in vivo. Several findings support the conclusion that this protection resulted from scavenging of $\circ \mathrm{OH}$. First, DMTU effectively scavenged ${ }^{\circ} \mathrm{OH}$ produced by gamma irradiation of water, as evidenced by inhibition of demethylation of DMSO. DMTU also scavenged ${ }^{\circ} \mathrm{OH}$ production from PMA-activated human PMN in vitro without evidence of impairment of other PMN functions, such as MPO activity, chemotaxis, degranulation, or aggregation. The concentrations of DMTU which inhibited ${ }^{\circ} \mathrm{OH}$ production by $\mathrm{PMN}$ in vitro were also effective in blocking edema in isolated rat lungs perfused with PMA-activated PMN, an injury known to be caused by PMN-derived oxidants (6). Finally, when rats were treated with DMTU in vivo to achieve concentrations in serum comparable with those in the in vitro studies, ${ }^{\circ H}$ scavenging activity was present in sera and the rats were protected against pulmonary oxygen toxicity, a lung injury involving toxic oxygen radicals (12-14) and PMN (15-17).

These studies are important because they suggest that DMTU may be a useful probe of the role of toxic oxygen radicals, particularly ${ }^{\circ} \mathrm{OH}$, in tissue and organ injury. Such a probe would be important because $(a)$ there are no known enzymatic scavengers of $\mathrm{OH}$ and $(b)$ previously described nonenzymatic chemical ${ }^{\circ} \mathrm{OH}$ scavengers, such as mannitol and ethanol, are so relatively low in their reactivity with ${ }^{\circ} \mathrm{OH}$ (19) that their effective use in vivo is precluded by their toxicities. Indeed, even the ${ }^{\circ} \mathrm{OH}$ scavenger DMSO, which is several times more reactive than either mannitol or ethanol (19) and relatively nontoxic (40), must be used in concentrations of $280 \mathrm{mM}$ to give the same degree of protection to bacteria against ${ }^{\circ} \mathrm{OH}$ as is afforded by $5 \mathrm{mM}$ DMTU (41).

The great reactivity of the DMTU molecule toward ${ }^{\circ} \mathrm{OH}$ is due to the sulfhydryl group as shown below on the right:<smiles>CNC(=S)NNC(C)=O</smiles><smiles>CCNC(S)=NC</smiles>

DMTU 
Table VIII. Effects of DMTU Treatment on Lung Edema and Lung Phagocyte Numbers of Rats Exposed to 100\% Oxygen for 66 h

\begin{tabular}{|c|c|c|c|c|c|c|c|}
\hline Treatment & Animal weights & $\begin{array}{l}\text { Lung weight:body } \\
\text { weight ratios } \\
\left(\times 10^{3}\right)\end{array}$ & $\begin{array}{l}\text { Lung lavage } \\
\text { albumin }\end{array}$ & Pleural effusions & $\begin{array}{l}\text { Blood PMN } \\
\left(\times 10^{3} / \mu \mathrm{l}\right)\end{array}$ & $\begin{array}{l}\text { Lung lavage } \\
\operatorname{PMN}\left(10^{6}\right)\end{array}$ & $\begin{array}{l}\text { Alveolar } \\
\text { macrophages } \\
\left(\times 10^{6}\right)\end{array}$ \\
\hline & $g$ & & $\mathrm{mg} / 100 \mathrm{ml}$ & $m l$ & & & \\
\hline \multicolumn{8}{|c|}{ Exposed to $100 \% \mathrm{O}_{2}$} \\
\hline Saline* & $332 \pm 6(11) \ddagger$ & $8.87 \pm 0.16(11)$ & $133 \pm 33(11)$ & $2.1 \pm 0.8(11)$ & $3.32 \pm 0.49(11)$ & $1.78 \pm 0.64(11)$ & $28.2 \pm 2.9(11)$ \\
\hline DMTU§ & $341 \pm 5(11)$ & $6.05 \pm 0.21(11)^{11}$ & $44 \pm 7 \quad(11)^{\prime \prime}$ & $0.1 \pm 0.1(11)^{\prime \prime}$ & $2.43 \pm 0.48(11) \pi$ & $1.49 \pm 0.41(13) \pi$ & $18.8 \pm 1.8(13)^{\prime \prime}$ \\
\hline \multicolumn{8}{|c|}{ Exposed to air } \\
\hline Saline & $302 \pm 4(6)$ & $5.78 \pm 0.33(6)^{*}$ & $10 \pm 5 \quad(6)$ & $0 \pm 0$ & $0.72 \pm 0.31(5)$ & $0 \pm 0(6)$ & $27.6 \pm 3.3(6)$ \\
\hline DMTU & $307 \pm 5(6) \Upsilon$ & $5.23 \pm 0.05(6) \pi$ & $20 \pm 5 \quad(6) \pi$ & $0 \pm 0$ & $1.17 \pm 0.21(6) \pi$ & $0.05 \pm 0.05(6) \pi$ & $30.6 \pm 4.9(6) \pi$ \\
\hline
\end{tabular}

* $4 \mathrm{ml}$, then $1 \mathrm{ml}$ every $12 \mathrm{~h} \times 5$. $¥$ Mean \pm SEM $(n) . \quad \$ 500 \mathrm{mg} / \mathrm{kg}$ intraperitoneally initially and $125 \mathrm{mg} / \mathrm{kg}$ intraperitoneally every $12 \mathrm{~h}$ thereafter. "Significantly less $(P<0.01)$ than saline-treated rats. I Not significantly different than saline-treated rats $(P>0.05)$.

The extremely favorable electron-donating characteristics of the sulfhydryl group may be due to the electron density around the carbon atom and the resonance stability inherent in the two enol and one keto forms. The parent compound, thiourea, shows similar ${ }^{\circ} \mathrm{OH}$ scavenging properties (19) for the same reasons, but cannot be used in vivo because it causes fatal pulmonary edema $(11,42)$. We previously showed that this was due to the oxidation in vivo of the primary amino groups of thiourea to a toxin, possibly cyanamide (10). From this, we reasoned that substitution of all the primary amino groups on the thiourea molecule with nonreactive substituents, such as the methyl groups in DMTU, would block the toxicity of the molecule without diminishing its antioxidant effectiveness. The present studies and previous studies (10) support this conclusion.

Several toxic oxygen radicals, such as $\mathrm{O}_{2}^{-}, \mathrm{H}_{2} \mathrm{O}_{2}$, and ${ }^{\circ} \mathrm{OH}$, could possibly contribute to lung injury. The present studies point toward ${ }^{\circ} \mathrm{OH}$ as being the primary cause of oxidant injury in the PMN-perfused isolated lung and in hyperoxic lung injury. First, $\mathrm{O}_{2}^{-}$does not appear to be primarily involved since DMTU did not scavenge $\mathrm{O}_{2}^{-}$from PMN in the present studies. Nevertheless, $\mathrm{O}_{2}^{-}$may be secondarily involved, since SOD has been associated with protection against both PMNinduced lung damage (8) and pulmonary oxygen toxicity (1214). Such secondary protection by SOD may result from the contribution of $\mathrm{O}_{2}^{-}$to the production of ${ }^{\circ} \mathrm{OH}$. Specifically, in biological systems, much ${ }^{\circ} \mathrm{OH}$ may arise from electron exchange between $\mathrm{O}_{2}^{-}$and $\mathrm{H}_{2} \mathrm{O}_{2}$ by the Haber-Weiss mechanism (43):

$\mathrm{O}_{2}^{-}+\mathrm{H}_{2} \mathrm{O}_{2} \stackrel{\mathrm{Fe}^{++-}-\mathrm{Fe}^{+++}}{\longrightarrow} \cdot \mathrm{OH}+\mathrm{OH}^{-}+\mathrm{O}_{2}$.

Recent studies have supported the role of this mechanism in acute inflammatory lung injury. For example, treatment of animals with the iron chelators, apolactoferrin or deferoxamine, protects against PMN-mediated tissue injury (7). Furthermore, protection of rats against pulmonary oxygen toxicity required both SOD and catalase (14).

Second, DMTU reacted relatively slowly with $\mathrm{H}_{2} \mathrm{O}_{2}$, making it less likely that scavenging of $\mathrm{H}_{2} \mathrm{O}_{2}$ was a major mechanism of protection in the present studies. Furthermore, while $\mathrm{H}_{2} \mathrm{O}_{2}$ can cause lung injury $(2,3)$, there are reasons to suspect that these effects are mediated principally by the reduction of $\mathrm{H}_{2} \mathrm{O}_{2}$ to $\mathrm{OH}(7-14)$ by means of the Fenton reaction (44):

$\mathrm{H}_{2} \mathrm{O}_{2}+\mathrm{Fe}^{++} \rightarrow \cdot \mathrm{OH}+\mathrm{OH}^{-}+\mathrm{Fe}^{+++}$.

Specifically, it has been shown that the ability of $\mathrm{H}_{2} \mathrm{O}_{2}$ to damage bacteria $(41,45)$ and DNA (46) is primarily dependent on its reduction to ${ }^{\circ} \mathrm{OH}$ because prevention of ${ }^{\circ} \mathrm{OH}$ formation from $\mathrm{H}_{2} \mathrm{O}_{2}$ by eliminating iron from the system prevents damage.

Since the first preliminary communications of the $\mathrm{OH}$ scavenging effectiveness of DMTU (47), there have been several preliminary reports of the use of DMTU as a probe for oxidant effects. DMTU prevented damage to AM exposed to hyperoxia in cell culture (48). DMTU also prevented lung edema in isolated rabbit lungs perfused with either PMN (49, 50) or an $\mathrm{O}_{2}^{-}$generating system (purine-xanthine oxidase) (3). DMTU or SOD prevented ischemic injury in the kidney (51), providing further support for the hypothesis that ischemic tissue injury may be mediated by oxygen radicals (52). Finally, the failure of DMTU to significantly decrease lung edema in sheep treated with intravenous endotoxin has suggested that 'OH may not contribute to this process (53).

\section{Acknowledgments}

I thank Dr. Steven Palder for performing the chemotaxis assays, Drs. C. Julianna Ching, Richard Parad, and Anne Arbetter for assistance with the isolated lung preparations, Dr. Catherine Wong and Dr. Robert Demling for collecting the DMTU samples from sheep, Dr. Amin Arnout for assistance with the degranulation studies, and Bradford S. Sumner for isolating the human granulocytes.

Dr. Fox is the recipient of a Clinical Investigator Award (5K08 HL-01131) from the Division of Lung Diseases of the National Institutes of Health. This work was supported by research grants from 
the American Lung Association, the National Institutes of Health (HL 30068), and the Council for Tobacco Research (grant No. 1666).

\section{References}

1. Fantone, J. C., and P. A. Ward. 1982. Role of oxygen-derived free radicals and metabolites in leukocyte-dependent inflammatory reactions. Am. J. Pathol. 107:397-418.

2. Johnson, K. J., J. C. Fantone III, J. Kaplan, and P. A. Ward. 1981. In vivo damage of rat lungs by oxygen metabolites. J. Clin. Invest. 67:983-993.

3. Tate, R. M., K. M. VanBenthuysen, D. M. Shasby, I. F. McMurtry, and J. E. Repine. 1982. Oxygen radical-mediated permeability edema and vasoconstriction in isolated perfused rabbit lungs. Am. Rev. Respir. Dis. 126:802-806.

4. Babior, B. 1978. Oxygen-dependent microbial killing by phagocytes. N. Engl. J. Med. 298:659-668, 721-725.

5. Tate, R. M., and J. E. Repine. 1983. Neutrophils and the adult respiratory distress syndrome. Am. Rev. Respir. Dis. 128:552-559.

6. Shasby, D. M., K. M. VanBenthuysen, R. M. Tate, S. S. Shasby, I. McMurtry, and J. E. Repine. 1982. Granulocytes mediate acute edematous lung injury in rabbits and in isolated rabbit lungs perfused with phorbol myristate acetate: role of oxygen radicals. Am. Rev. Respir. Dis. 125:443-447.

7. Ward, P. A., G. O. Till, R. Kunkel, and C. Beauchamp. 1983. Evidence for role of hydroxyl radical in complement and neutrophildependent tissue injury. J. Clin. Invest. 72:789-801.

8. Till, G. O., K. J. Johnson, R. Kunkel, and P. A. Ward. 1982. Intravascular activation of complement and acute lung injury: dependency on neutrophils and toxic oxygen metabolites. J. Clin. Invest. 69:1126-1135.

9. Crapo, J. D., D. M. DeLong, K. Sjostrom, G. R. Hasler, and R. T. Drew. 1977. The failure of aerosolized superoxide dismutase to modify pulmonary oxygen toxicity. Am. Rev. Respir. Dis. 115:10271033.

10. Fox, R. B., R. N. Harada, R. M. Tate, and J. E. Repine. 1983. Prevention of thiourea-induced pulmonary edema by hydroxyl radical scavengers. J. Appl. Physiol. Respir. Environ. Exercise Physiol. 55:14561459.

11. Dieke, S. H., G. S. Allen, and C. P. Richter. 1947. The acute toxicity of thioureas and related compounds to wild and domestic Norway rats. J. Pharmacol. Exp. Ther. 90:260-270.

12. Crapo, J. D., and D. F. Tierney. 1974. Superoxide dismutase and pulmonary oxygen toxicity. Am. J. Physiol. 226:1401-1407.

13. Frank, L., J. Summerville, and D. Massaro. 1980. Protection from oxygen toxicity with endotoxin: role of the endogenous antioxidant enzymes of the lung. J. Clin. Invest. 65:1104-1110.

14. Turrens, J. F., J. D. Crapo, and B. A. Freeman. 1984. Protection against oxygen toxicity by intravenous injection of liposomeentrapped catalase and superoxide dismutase. J. Clin. Invest. 73:8795.

15. Fox, R. B., J. R. Hoidal, D. M. Brown, and J. E. Repine. 1981. Pulmonary inflammation due to oxygen toxicity: involvement of chemotactic factors and polymorphonuclear leukocytes. Am. Rev. Respir. Dis. 123:85-89.

16. Shasby, D. M., R. B. Fox, R. N. Harada, and J. E. Repine. 1982. Reduction of the edema of acute hyperoxic lung injury by granulocyte depletion. J. Appl. Physiol. 52:1237-1244.

17. Shasby, D. M., S. S. Shasby, C. M. Bowman, R. B. Fox, R. N. Harada, R. M. Tate, and J. E. Repine. 1981. Lung lavage angiotensin converting enzyme levels in normal and nitrogen mustard treated rabbits exposed to hyperoxia. Am. Rev. Respir. Dis. 124:202-203.

18. Repine, J. E., J. W. Eaton, M. W. Anders, J. R. Hoidal, and R. B. Fox. 1979. Generation of hydroxyl radical by enzymes, chemicals and human phagocytes in vitro. Detection using the anti-inflammatory agent, dimethyl sulfoxide. J. Clin. Invest. 64:1642-1651.

19. Dorfman, L. M., and G. E. Adams. 1973. Reactivity of the hydroxyl radical in aqueous solutions. U. S. Department of Commerce, National Bureau of Standards. NSRDS-NBS No. 46:1-59.

20. Chance, B. 1949. The properties of the enzyme-substrate compounds of horseradish peroxidase and peroxides. Arch. Biochem. Biophys. 24:410-421. MO.

21. Horseradish peroxidase assay. Sigma Chemical Co., St. Louis,

22. Nelson, R. D., P. G. Quie, and R. L. Simmons. 1975. Chemotaxis under agarose: a new and simple method for measuring chemotaxis and spontaneous migration of human polymorphonuclear leukocytes and monocytes. J. Immunol. 115:1650-1656.

23. Worthington enzyme manual. 1972. Worthington Biochemical Corp., Freehold, NJ. 109-110.

24. Talalay, P., W. H. Fishman, and C. Higgins. 1946. Chromogenic substrates. II. Phenolphthalein glucuronic acid as substrate for the assay of glucuronidase activity. J. Biol. Chem. 166:757-772.

25. Worthington enzyme manual. 1972. Worthington Biochemical Corp., Freehold, NJ. 7-10.

26. Gottlieb, C., K.-S. Lau, L. R. Wasserman, and V. Herbert. 1965. Rapid charcoal assay for intrinsic factor (IF), gastric juice unsaturated $B_{12}$ binding capacity, antibody to IF, and serum unsaturated $\mathrm{B}_{12}$ binding capacity. Blood. 25:875-893.

27. Hammerschmidt, D. E., J. G. White, P. R. Craddock, and H. S. Jacob. 1979. Corticosteroids inhibit complement-induced granulocyte aggregation. J. Clin. Invest. 63:798-803.

28. Doumas, B. T., W. A. Watson, and H. G. Biggs. 1971. Albumin standards and the measurement of serum albumin with bromocresol green. Clin. Chim. Acta. 31:87-96.

29. Sigma Technical Bulletin No. 630. Sigma Chemical Co., St. Louis, MO.

30. Staub, N. C., R. D. Bland, K. L. Brigham, R. H. Demling, J. Erdman, and W. Woolverton. 1975. Preparation of chronic lung lymph fistulas in sheep. J. Surg. Res. 19:315-320.

31. Kobayashi, H., O. Matano, and S. Goto. 1981. Simultaneous quantitation of thioureas in rat plasma by high-performance liquid chromatography. J. Chromatogr. 207:281-285.

32. Sawchuck, R. J., and D. E. Zaske. 1976. Pharmacokinetics of dosing regimes which utilize multiple intravenous infusions: gentamicin in burn patients. J. Pharmacokin. Biopharm. 4:183-195.

33. Snedecor, G. W., and W. G. Cochran. 1980. Statistical Methods. Iowa State University Press, Ames, IA. 215-237.

34. Werner, E. A. 1912. The interaction of iodine and thiocarbamide: the properties of formamidine disulfide and its salts. J. Chem. Soc. 101(2):2166-2180.

35. Beers, R. F., and I. W. Sizer. 1952. A spectrophotometric method for measuring the breakdown of hydrogen peroxide by catalase. J. Biol. Chem. 195:133-140.

36. Klebanoff, S. J. 1975. Antimicrobial mechanisms in neutrophilic polymorphonuclear leukocytes. Semin. Hematol. 12:117-142.

37. Kane, S. P., and T. J. Peters. 1975. Analytical subcellular fractionation of human granulocytes with reference to the localization of vitamin $\mathrm{B}_{12}$ binding proteins. Clin. Sci. Mol. Med. 49:171-182.

38. Craddock, P. R., J. Fehr, A. P. Delmasso, K. L. Brigham, and 
H. S. Jacob. 1977. Hemodialysis leukopenia: pulmonary vascular leukostasis resulting from complement activation by dialyzer cellophane membranes. J. Clin. Invest. 59:879-888.

39. Harada, R. N., A. E. Vatter, and J. E. Repine. 1983. Oxygen radical scavengers protect alveolar macrophages from hyperoxic injury in vitro. Am. Rev. Respir. Dis. 128:761-762.

40. Rubin, L. F. 1983. Toxicologic update on dimethylsulfoxide. Ann. NY. Acad. Sci. 411:6-10.

41. Repine, J. E., R. B. Fox, and E. M. Berger. 1981. Hydrogen peroxide kills Staphylococcus aureus by reacting with staphylococcal iron to form hydroxyl radical. J. Biol. Chem. 256:7094-7096.

42. MacKenzie, J. B., and C. G. MacKenzie. 1943. Production of pulmonary edema by thiourea in the rat, and its relation to age. Proc. Soc. Exp. Biol. Med. 54:34-37.

43. Haber, F., and J. Weiss. 1934. The catalytic decomposition of hydrogen peroxide by iron salts. Proc. R. Soc. Lond. Ser. A. 147:332351.

44. Walling, C. 1975. Fenton's reagent revisited. Acc. Chem. Res. 8:125-131.

45. Repine, J. E., R. B. Fox, E. M. Berger, and R. N. Harada. 1981. Effect of staphylococcal iron content on the killing of Staphylococcus aureus by polymorphonuclear leukocytes. Infect. Immun. 32:407410.

46. Repine, J. E., O. W. Pfenninger, D. W. Talmage, E. M. Berger, and D. E. Pettijohn. 1981. Dimethyl sulfoxide prevents DNA nicking mediated by ionizing radiation or iron/hydrogen peroxide-generated hydroxyl radical. Proc. Natl. Acad. Sci. USA. 78:1001-1003.

47. Fox, R. B., R. M. Tate, C. M. Bowman, D. M. Shasby, R. N. Harada, and J. E. Repine. 1981. Hydroxyl radical mediated pulmonary edema: the paradox of thiourea. Clin. Res. 29:446a.

48. Harada, R. N., R. B. Fox, C. M. Bowman, R. M. Tate, D. M. Shasby, D. W. Talmage, and J. E. Repine. 1981. Hyperoxia damages and stimulates alveolar macrophages to release chemotaxins for neutrophils: damage to alveolar macrophages is prevented by thiourea. Clin. Res. 29:68a. (Abstr.)

49. Shasby, D. M., K. M. VanBenthuysen, R. M. Tate, I. F. McMurtry, and J. E. Repine. 1981. Oxygen radicals released from phorbol myristate acetate stimulated granulocytes cause acute pulmonary vascular injury. Am. Rev. Respir. Dis. 123:248a. (Abstr.)

50. Jackson, J. H., C. W. White, W. R. Schroeder, N. B. Parker, and J. E. Repine. 1984. Dimethylthiourea disappearance parallels the amount of hydrogen peroxide added and indicates the degree of acute edematous injury in isolated perfused rat and rabbit lungs. Clin. Res. 31:782a. (Abstr.)

51. Paller, M. S., J. R. Hoidal, and T. F. Ferris. 1984. Oxygen free radicals in ischemic acute renal failure in the rat. J. Clin. Invest. 74:1156-1164.

52. Granger, D. N., G. Rutili, and J. M. McCord. 1981. Superoxide radicals in feline intestinal ischemia. Gastroenterology. 81:22-29.

53. Wong, C., R. B. Fox, and R. H. Demling. Effect of hydroxyl radical scavenging on endotoxin-induced lung injury. Surgery. In press. 